\title{
KÖNYVISMERTETŐ
}

\section{Elveszte(get)ett évtized(ek) az Európai Unióban?}

Farkas Beáta (szerk.):

The Aftermath of the Global Crisis in the European Union.

Cambridge Scholars Publishing,

Newcastle upon Tyne, 2013

Napjainkban a közgazdasági tudományos élet, megjelent tudományos publikációk, közgazdasági viták teljesen átitatottak a 2007-2008-as gazdasági válság hatásaival, következményeivel, és még napjainkban is számtalan olyan tanulmány található, amelyek az okokat igyekeznek feltárni újabb és újabb módszerekkel. Bármilyen jellegú - de gazdasági tartalmú - olvasmányt veszünk a kezünkbe, ami az elmúlt néhány évben jelent meg, biztosan találkozunk benne a válság, válságkezelés, válságmenedzsment szóval. Foglalkozzunk akár makrogazdasági, akár regionális, akár nemzetközi kérdésekkel, esetleg üzleti tudományokkal, vagy például fogyasztói preferenciák vizsgálatával, nem hagyhatjuk figyelmen kívül ezt a globális folyamatot. Ebból kifolyólag mára - talán a médiának is köszönhetően - mindenkinek jól kialakult véleménye van e válság gazdasági hatásairól, folyamatáról, hátteréról. Egy ilyen környezetben merész vállalkozás egy olyan kötettel „megjelenni a piacon”, ami a válsággal foglalkozik. Egy - különösen egy nyomtatott formában is megjelent - könyvvel szemben ugyanis további elvárás az, hogy időtálló legyen. Úgy hiszem, hogy a Farkas Beáta szerkesztésében elkészült kötet teljesíteni tudja ezt az elvárást: a 11 - angol nyelvú - tanulmányból álló könyv 2013-ban jelent meg a Cambridge Scholars Publishing gondozásában.

A "The Aftermath of the Global Crisis in the European Union" címú kötetet Farkas Beáta, a Szegedi Tudományegyetem Gazdaságtudományi Karának intézetvezetô egyetemi docense szerkesztette. A könyv alapját a 2012 tavaszán, a Szegedi Tudományegyetem által szervezett nemzetközi konferencia (Crisis Aftermath: Economic policy changes in the EU and its Member States) adja. A könyv bevezetôjét Farkas Beáta írta, és ugyan nem jelenik meg markánsan, de a kötet központi kérdése, melyre a benne szereplő tanulmányokat felfúzték, talán így fogalmazható meg a legegyszerúbben: „,Mi lesz veled, Európai Unió?" Már ez a kérdés is jelzi azt, hogy inkább a jövőbeli opciókat vázolják a kötet tanulmányainak szerzói, így nem egy újabb, a válság mögött meghúzódó okokat vizsgáló könyvet vehetünk kézbe. Mindezzel pedig igenis aktuális, és a valóságra ráébresztő, elgondolkodtató kötetet tanulmányozhatunk.

Akötetben szereplőtanulmányok szerzói széles spektrumot fednek le, és a tudományos szakma több területének képviselójének elemzése jelent meg. A szerzók között ugyanis megtalálható az Európai Számvevőszék (Luxemburg) mellett a Bruegel Intézet (Brüsszel), a Turkui Egyetem (Finnország), a Kobe Egyetem (Japán), a görög American College, valamint a European Policy Centre (Brüsszel) kutatója. Továbbá a Ma- gyar Költségvetési Tanács elnöke, a Múegyetem (Budapest), a Pannon Egyetem (Veszprém) és a Szegedi Tudományegyetem tudományos kutatói írásait is közli a könyv. Mindez lehetővé teszi azt, hogy a kötet központi kérdését olyan szakemberek szemszögéből is megismerhessük, akik közvetlen közelról tapasztalják az európai uniós döntéshozatalt. Már a szerzók miatt is érdemes e kötetet a kezünkbe venni.

A kötet 11 tanulmánya három fejezetben jelenik meg. Az első rész - három elemzésen keresztül a gazdasági növekedés lehetôségeit elemzi, több szemszögból: milyen kihívásokkal találkozunk, és azokat hogyan lehet kezelni, milyen eszközök állnak rendelkezésre a gazdasági növekedés felgyorsítására, és milyen konzekvenciákat lehet levonni a japán recesszió következményeiből, kezeléséből. A második fejezet - szintén három tanulmányt tartalmazva - a fiskális és a monetáris politika kihívásait taglalja: az EU-költségvetés mellett az EU-válság gyökereit is megismerhetjük, valamint a Gazdasági és Monetáris Unió gyengülő szerepéról kaphatunk általános képet. A kötet harmadik része - öt tanulmányra épülve - a kohéziós országok (közép- és kelet-európai országok, mediterrán országok) problémáit és lehetôségeit igyekszik feltárni: az európai konvergenciamodellben látható töréspont, a közép- és kelet-európai országok válságkezelésének hasonlóságai és különbségeit taglaló fejezetek után ezen országok eurózónához való csatlakozásának lehetőségeit is megismerhetjük, valamint részleteket kaphatunk a gö- 
rög fiskális politika válságkezelési eszközeiról és a magyar lassú gazdasági növekedésének okairól is.

A fejezeteket és a címeket áttekintve mindenképpen egy jól felépített kötetet lapozhatunk fel: az általánosabb kérdések (az EU jövôje, az EU fiskális politikája) felől haladunk konkrétabb, kisebb egységek felé (Közép-Kelet-Európa, Görögország, Magyarország). Két kiugró elemre szeretném felhívni a figyelmet: egyrészt a kötet erősségének tekinthető $\mathrm{az}$, hogy Japán is bekerült egy alapvetően EU-s folyamatokat taglaló múbe. Másrészt a szerkezetet áttekintve egyértelmúvé válik, hogy a kötet nagyobbrészt a kelet-európai és a kohéziós országokkal foglalkozik, rámutatva arra, hogy ezek az országok teljesen más lehetőségekkel rendelkeznek, mint a nyugati országok, és hogy ezek az országok más problémákkal is szembesültek: a konvergenciafolyamat korlátozottnak tünik. Kiemelendő, hogy a kötet hangsúlya inkább a kelet-európai országok felé tolódik, így nem Írország, Spanyolország vagy Portugália, esetlegesen Olaszország gazdasági gondjairól kaphatunk egy újabb áttekintést, hanem egy olyan területről, amelyben közvetlenül is élünk.

A könyvben szereplő tanulmányok módszertani háttere ugyanolyan változatos, mint a szerzók maguk. Ez azonban egyáltalán nem probléma. A kötetben szereplố tudományos közleményeket három csoportba lehet sorolni a módszer alapján: egy része elméleti fejtegetésre épül, másik része leíró statisztikát alkalmaz, míg a harmadik csoportba az ökonometriai módszereket is felvonultató kutatások sorolhatók. Ebból kifolyólag, véleményem szerint, a végkövetkeztetések kellóen megalapozottak, és a változatosság miatt minden irányultságú kutató megtalálhatja a számára vonzó részeket a tanulmányokban.

A kötet első nagyobb egysége az európai gazdasági növekedés kilátásait taglalja. A fejezet elsô részében Fabian Zuleeg azt vizsgálja, hogy az európai válságnak milyen hosszú távú hatásai vannak, és hogy ez a válság hasonlítható-e a Japán által átélt két elvesztegetett évtizedhez. Az Európai Uniónak ugyanis a válságon és annak kezelésén túl olyan kihívásokkal is szembe kell nézni, mint a globalizáció, az eróforrásokért folyó verseny, a növekvő egyenlőtlenség és növekvő munkanélküliség, a demográfiai kihívások (elöregedố társadalom), valamint a klímaváltozás. Ezek pedig az EU hoszszú távú növekedési lehetőségeit befolyásolják, így - véli a szerzó - ha nem próbálnak meg reagálni ezekre a kihívásokra, akkor az Európai Unió akár Japán útjára is „tévedhet”, és az EU vonatkozásában is beszélhetünk majd elvesztett (vagy elvesztegetett?) évtizedról. A szerző viszont hangsúlyozza azt is, hogy ez az EU esetében nem feltétlenül fog látványos visszaesésben testet ölteni, sokkal inkább a növekedés ütemének lassulásáról lehet majd beszélni. A szerző a helyzet megoldásaként komoly szerepet szán az európai polgároknak, és nem kizárólag az EU-s intézmények szerepének változásában látja a probléma megoldását.

Fabian Zuleeg gondolatmenetét folytatva Matti Viren tanulmányában már arra is választ kaphatunk, hogy miként lehetne az európai gazdasági növekedést gyorsítani. Ennek alapjául pedig a munkaerópiac múködését, az árversenyt és a kormányzat növekedését tekinti, és elemzéséhez ökonometriai modellt használ. Bár az eredmények biztatóak, hiszen a szerzô kimutatta, hogy van lehetôség az európai gazdasági növekedés gyorsítására, azonban azt is beismeri, hogy ehhez népszerútlen reformok megtételére van szükség.

Ez a két tanulmány azt taglalta, hogy milyen sokkokérhetik Európát hosszú távon, ha nem cselekszik rövid idôn belül. Így a japán recesszió - ami már két évtizede tart - és az az elleni törekvések akár tanulságul is szolgálhatnak Európa számára. Így e fejezet zárótanulmánya érdekes válaszokkal szolgálhat: Masahiko Yoshii ugyanis Japán elvesztegetett évtizedeit elemzi. Olyan kérdésekre tér ki, hogy mi volt Japán hosszúra nyúlt recessziójának oka; hogyan lehetne a válságon túllendülni a keresletoldali (fiskális és monetáris politikai) és kínálatoldali eszközök (mint termelékenység növelése) alkalmazásával; valamint a válságnak milyen hatásai voltak a japán gazdaságra nézve. Amiból komoly tanulságokat lehet levonni Európa számára: azt is bemutatja a tanulmány, hogy milyen lépéseket tett Japán a recesszióból való kilépésre, beleértve a fiskális és monetáris politikai intézkedéseket, valamint a strukturális reformokat is. Az európai politika számára rendkívül fontos üzenet az, hogy a japán példát figyelembe véve önmagában a fiskális politikai törekvések, megoldási eszközök nem lehetnek hatékonyak a válságkezelésében, ahhoz ugyanis a vállalatok, a kormányok, az Európai Központi Bank fellépésére is szükség van. A szerzó nagyon negatív képet fest az európai jövőról: ha ez nem történik meg, és csak fiskális oldalról kezelik a tüneteket, akkor szerinte - Japánhoz hasonlóan - legalább két elvesztegetett évtizeddel kell számolni Európában is.

A kötet következó nagyobb fejezete továbbviszi ezt a gondolatmenetet, és a fiskális és monetáris politikai kihívásokat taglalja. Gabriele Cipriani az EU költségvetését mint a fiskális politika egy 
különleges területét elemzi, és betekintést ad az EU-szintú és a nemzeti szintû költségvetési gyakorlatba. Rávilágít arra is, hogy az EU és a nemzeti költségvetések - közpénzügyek - hogyan hatnak egymásra, és az EU-s tevékenységek (célok) mennyiben tudják befolyásolni a nemzeti költségvetés mozgásterét.

Darvas Zsolt kritikai szemmel figyeli az európai válságmenedzsmentet. Tanulmányában tíz pontban foglalja össze, hogy milyen okai voltak az európai válság kialakulásának, azokra milyen politikai válaszok születtek (ha egyáltalán születtek), és igyekszik választ adni arra a kérdésre is, hogy miért olyan nehéz a válságot kezelni. Az okok között olyan tényezóket említ meg, mint például a stabilitási és növekedés paktum problémái, a strukturális alkalmazkodás elmaradása, a tagállamok közötti függôségek, vagy az egységes európai fiskális politika hiánya. A szerzó úgy véli, hogy hiába kezeljük a válságot, ha a dél-európai gazdasági problémákra eddig nem született megoldás.

A monetáris politika gondolatmenetét viszi tovább a fejezet zárótanulmánya is: Losoncz Miklós a Gazdasági és Monetáris Unió gyengülésének okait vizsgálta, arra fókuszálva, hogy az intézményrendszer és a monetáris unió között milyen kapcsolat figyelhetô meg, valamint részletezi azokat az eszközöket, amelyek a monetáris unió pilléreit gyengítették, és a válság kezelésének lehetôségeit is vázolja.

A könyv következő fejezete tartalmazza a legtöbb tanulmányt: a kohéziós országok válsággal való küzdelmét ismerteti. Az egység első elemzésében Farkas Beáta azt vizsgálja, hogy a válság fordulópontot jelent-e az európai konvergenciamodellben. A szerző kritizálja azokat az állításokat, melyek szerint ezek az országok jelenleg csak lassuló növekedést tapasztalnak, hiszen sokkal inkább a felzárkózás elmaradása látszódik, és úgy túnik, hogy ezek az országok a válság elő́tti idôszakban tapasztalt felzárkózási útra nem tudnak majd visszaállni. Ebból kifolyólag a szerzố azt vizionálja - amiról ma már egyre gyakrabban esik szó -, hogy többsebességes Európa alakul ki, ez pedig majd magának a kohéziós politikának az átalakítását is igényli majd.

Kovács Árpád az újonnan csatlakozott országokban megvalósult - vagy megvalósítás alatt lévő válságkezelési eszközöket elemzi és hasonlítja össze. A szokásos módszerek helyett a hangsúly a költségvetési és a közpénzügyi kérdések felé tolódik, azaz a fiskális politika szemszögéból elemzi a kérdést. Kiss Gábor Dávid és Kosztopulosz Andreász viszont már ökonometriai modell alkalmazásával a válság monetáris politikai hatását vizsgálják: azt elemzik, hogy három közép-kelet-európai ország (Csehország, Lengyelország, Magyarország) számára mennyire jó az árstabilitás mint jegybanki cél, valamint mennyire lehet kedvezô a gazdasági és monetáris unióhoz való csatlakozás. A modell felépítéséhez kötvény-, valutapiaci és tôzsdei adatokat használtak fel. Ahhoz, hogy pénzügyi stabilitás fenntartható legyen, az árstabilitást kell továbbra is követni, viszont ehhez mindenképpen szükséges az intézményi háttér fejlesztése ebben a három országban.

$\mathrm{Az}$ általánosabb megközelítések után Visvizi Anna tanulmánya Görögország elemzésére szúküll. A szerző a görög fiskális politikai eszközök eredményességét igyekszik feltárni elemzésében. Ennek eredményeként egy részletes áttekintést kapunk a 2010. május és 2012. június közötti időszakban megtett lépésekról, intézkedésekról, azok hatásairól.
Az országtanulmányok közül azonban Magyarország sem maradhat ki, hiszen hazánk a 90-es években még követendô példa volt, azóta azonban az EU elmaradott országai között foglalunk helyet. A megváltozott helyzet miatt mindenképpen indokolt Magyarország lehetőségeinek vizsgálata, és a kötet így méltán zárul egy ilyen elemzéssel: Mihályi Péter azt vizsgálja, hogy milyen okai lehetnek Magyarország lassú gazdasági növekedésének. Úgy véli, hogy a meglévő humán és tốkeállomány hatékonyabb elosztása lehet a kulcs a gyorsabb növekedéshez. Emellett azt a megállapítást teszi, hogy a nagy cégek hiánya nem teszi lehetôvé a méretgazdaságossági előnyök kihasználását, így tulajdonosi koncentrációra lenne szükség egyes területeken (például mezőgazdasági föld, erdő), és a kis- és középvállalatoknak is növekedniük kellene legalább közepes céggé. Összességében viszont az alacsony termelékenységre vezethető vissza a magyar gazdasági növekedés alacsony foka.

A kötetet áttekintve egyértelmúen állíthatom, hogy a könyvben szereplő tanulmányok magas szakmai színvonalúak, alaposan és megfontoltan lettek kiválogatva. A kötetet haszonnal tudják forgatni a pénzügyek, a fiskális politika iránt érdeklódök, az általánosabb makrogazdasági kérdéseket feszegetốk, valamint az ökonometriai elemzéseket szívesen alkalmazók is. Összességében a könyv kiváló és széles áttekintést ad az Európai Unió válságkezeléséról, de ami még inkább a könyv erőssége: arra helyezi a hangsúlyt, hogy az elhúzódó válság egyrészt milyen problémát okozhat hosszú távon Európában, másrészt arra, hogy a közép-keleteurópai országok hogyan tudnak mindezzel szembenézni.

Udvari Beáta 